\title{
Analyzing Learner Language to Better Understand Errors: A Case Study with Turkish Learners of English
}

\author{
Heather M. Austin ${ }^{1, *}$ \\ ${ }^{1}$ School of Second Foreign Languages, Izmir University of Economics, Izmir, Turkey \\ *Correspondence: Izmir University of Economics, Sakarya Caddesi No: 156, Izmir 35330, Turkey. E-mail: \\ hmaustin@live.com
}

Received: October 20, 2017

Accepted: November 11, 2017 Online Published: December 5, 2017

doi:10.5430/ijelt.v5n $1 \mathrm{p} 9$

URL: https://doi.org/10.5430/ijelt.v5n1p9

\begin{abstract}
Analyzing the errors of students' learner language (interlanguage) can help language instructors to not only better understand why the errors may be occurring, but also provide them with insight on how to better guide learners in their L2 learning. In this paper, the learner language of two Turkish students of English was analyzed regarding the third person singular $-s$ inflection and interaction strategies. The author met with each student three times and speech data was collected during these meetings. An error and interlanguage analysis was then conducted. Reflecting on these types of analyses can be a very enlightening process in a teacher's continuing education. Various implications arise, such as more objectivity in approaching student errors, creating better learning opportunities in the classroom, as well as having a better indication of where students are at in their own second language acquisition process.
\end{abstract}

Keywords: EFL, Turkish, interlanguage analysis, error analysis, interaction in interlanguage development, psycholinguistics, professional development

\section{Introduction}

Analyzing learner language - termed 'interlanguage' (IL) by Selinker (1972) (as cited in Cook, 2008) - is a worthwhile endeavor; it can not only gauge where the learner is in his or her second language (L2) development, but it can also provide teachers with insight on how to better guide them in their learning. This is something Corder (1967) would agree with, as he believes L2 errors are evidence of learning and that knowledge of this can improve teachers' ability to create favorable learning conditions.

According to Larsen-Freeman and Long (1991), a learner's IL is sometimes seen as a continuum between the L1 and the L2 that learners traverse. They say it has three main assumptions: (1) it is the patterned product of a linguistic system within the learner, (2) it is different from the learner's L1 and the target language (TL), and (3) it is not the same as any other learner's IL, even if they are at the same proficiency level, because they have different language learning experiences (p. 60). This is important to know when doing IL analysis, particularly because the role of the learner is seen as an active one in "processing input, generating hypotheses, testing them and refining them," (Larsen-Freeman and Long ibid.: 61). The IL truly belongs to and cannot be separated from the learner. With all this in mind, the ILs of two Turkish-speaking learners of English were analyzed and interpreted in terms of second language acquisition (SLA) theory.

\section{Methodology}

Over four weeks, the author met with both students three times - twice individually and once all together. The first meeting was designed to elicit errors from the students for the author to analyze, focusing on one for the remainder of the case study. Interaction and the third person singular $-s$ inflection were chosen as the main focus. The second meeting aimed to elicit this error, and an error and interlanguage analyses followed. The third meeting again sought to elicit this error with a heavier focus on interaction. These processes were then reflected upon in terms of their impact on the author and her professional development. 
There were two participants involved in this case study: Student T and Student B (aliases are used for confidentiality purposes). Both are native Turkish speakers learning English in the preparatory English department of a university in Izmir, Turkey. They are studying at the highest of four levels, D Level (exit level B2 on the Common European Framework of Reference (CEFR)). Despite their supposed high level of study, their spoken English is quite weak. When comparing the two students, Student B performs at a slightly more proficient level than Student $T$ as she is more capable of stringing together full sentences and has better fluency skills, though errors still often occur. Student $\mathrm{T}$ has more problems forming syntactically accurate sentences in English, although he still speaks with confidence.

\section{Results and Discussion}

\subsection{Meeting 1 and Analysis}

The author met with both students separately and asked them the same basic background questions (Appendix A) to see what errors they might make in their speech. Based on this interview, a few linguistic features of their ILs stood out. One of them is that the syntax in some of their utterances was similar to that of their L1. English has a SVO word order, whereas Turkish has a word order of SOV. Turkish word order is evident in Appendix B-E. when Student T tries to say "I know one or two words," - it should be noted that Turkish is a pro-drop, agglutinative language, so the "I know" in this example is consistent with the SOV word order of Turkish, not OSV as it looks on the surface. Similarly, Student B's utterance in Appendix C-D. also exhibits Turkish word order when she attempts to say "It has unnecessary words," and in Appendix C-E. when trying to say "She only learned by listening." In addition, it is also important to point out the syntactic flexibility of spoken Turkish in certain situations - the subject and verb can move positions depending on if the speaker wants to highlight the action or the object, thus reflecting an OVS or VSO word order. In English, this kind of emphasis is displayed by reconstructing the sentence altogether or by changing one's intonation while speaking (Appendix D). In one instance, Student T's English reflected a Turkish word order in these regards. As can be seen in Appendix B-G., Student T puts the subject Balçova (the name of the neighborhood he lives in) at the end of the sentence, thus reflecting a Turkish OVS word order, even though what he really means is "Balçova is not [a] good [place] to study English."

In the examples above, first language interference may be at play as these students have not yet been able to completely reset the word order parameter from their L1 to the correct parameter for their L2, a concept from Chomsky's (1957) Universal Grammar (UG) theory. This theory states that all learners of language have innate knowledge of grammar in their minds which consists of principles that are universally the same in all languages and parameters which vary among all languages (Cook, 2008). In regards to Student T and B, the concept and existence of word order is the principle, but what that word order looks like (SVO vs. SOV vs. OVS) differs between English and Turkish and is thus the parameter. Cook (1985) offers further explanation in this regard in that L2 learners may use their L1 knowledge as a springboard for constructing L2 knowledge, noting that existing parameters can be "adapted and reset to create a second grammar for the L2, using the still accessible [L1] UG in the mind," (Cook and Newson, 2007, p. 235). If this is the case, these two students have not yet mastered the different word order parameter of the L2 and may have difficulty in doing so because of their L1 parameter knowledge. Therefore, cross-linguistic influence, that is, the phenomena that result from language contact, may be able to account for this issue of L1 interference (Larsen-Freeman and Long, 1991).

Another linguistic feature that may have been affected by the students' L1 was when both Student T and Student B left out the copula $b e$ in some of their English sentences (Appendix B-C./D./E./G. and Appendix C-B.). Verb be as the main verb of the sentence does not exist in Turkish the way it does in English, so this could be a reason why they also omitted it in some of their utterances - perhaps again not having reset their parameters yet. This is also related to Krashen's (1985) Natural Order Hypothesis, stating that learners "pass through predictable stages in their acquisition of grammatical structures...[and] that these orders [are] independent of instructional sequences or even the complexity of the structures to be acquired," (VanPatten and Williams, 2015, p. 26). He lists some of these stages in his (1982) proposal of Second Language Grammatical Morpheme Acquisition Sequence, where copula be is listed as being one of the first stages learners pass through. However, despite these students' D-Level, advanced-English status, they have still not yet acquired this grammatical item, possibly due to their L1 knowledge pertaining to the structure.

Two other aspects of language were also prevalent in the speech data: monitoring and production of learner chunks. According to Krashen, monitoring is a student's conscious effort to produce accurate language either before or after production by taking time to edit or correct their output as they mentally reference the language rules they have learned. Student T monitors his output in Appendix B-A./E./F./H. as he pauses for a moment to try to find the right 
word or phrase and occasionally self-corrects himself. Student B also monitors her output in these ways in Appendix C-D./F. Here, their learned language systems are trying to polish up their acquired systems. Learner chunks were also present in Student T's speech in Appendix B-D. He may have confused the reflexive pronouns because he is used to hearing yourself when discussing generic you (where you is anyone or people in general), such as in, "You can help yourself by talking to a therapist." Changing the reflexive pronoun to be more specific to a third person (herself/himself) is less common, and so he simply said the chunk he is used to hearing in its place.

The last aspect of their language use that was prevalent in meeting 1 is their inaccuracies in using the third person singular $-s$ inflection. These two students are in the highest level of their preparatory English studies at their university, and yet they both still make a noticeable amount of errors with this grammar point (Appendix B-A./D./H./I. and Appendix C-A./E). This may be because subject-verb agreement differs greatly between Turkish and English. Turkish is an agglutinative language, so suffixes added to the base form of the verb demonstrate who the speaker is referring to. Each subject (I, you informal, you formal, he/she/it, we, they) has a different verb ending suffix, but these 6 marked features in Turkish are reduced to just two in English. For example, (1) I/you/we/they like, and (2) he/she/it likes. They undoubtedly have issues with this, possibly because they overgeneralize or confuse the rule. In addition, he/she/it in English is expressed by one gender neutral word in Turkish, $O$, which may also cause issues. Another possibility is that because of these cross-linguistic influences, these learners are showing a delay in passing through this particular acquisition sequence. In fact, the third person singular $-s$ is one of the last grammatical morphemes mastered according to Krashen's Second Language Grammatical Morpheme Acquisition Sequence, which may explain why they still have this difficulty despite currently studying at a higher level (Larsen-Freeman and Long, 1991). Both students were introduced to this structure in A Level (exit level A1+ on the CEFR) and have practiced it for nearly six months as they passed through two other levels (B and C Levels), yet they still make errors.

However, in spite of the general lack of control these two students seem to have over this natural order morpheme, there are some instances in which they use it correctly (Appendix B-G. and Appendix C-B.). As such, it is possible that their errors are the result of them being in the second stage of what is called "U-shaped" language behavior, a concept discussed by Kellerman (1985). This is when language learners exhibit systematic language behavior in three distinct stages: Stage 1 - language performance is error-free; Stage 2 - performance which deviates from the norms of the TL; and Stage 3 - deviations diminish and performance is again error-free, as it was in Stage 1. In Stage 2, learners use a particular structure more ungrammatically than in Stage 1 or 3, so perhaps these two learners are currently at Stage 2 in their development of this particular morpheme.

Despite the many instances of language use that revealed the different states of these students' ILs during the first meeting, the remainder of this paper will continue to focus on only one structure: the third person singular $-s$ inflection. As this error is considered to be a basic "A Level error" being made by D Level students and is a common error of Turkish learners of English, it was chosen as the focal point for meetings 2 and 3.

\subsection{Meeting 2}

The second individual meeting focused on getting each student to produce the third person singular $-s$ when speaking by using an elicitation instrument created by the author. The task entailed the description and weekend routine of a famous athlete and his wife (Appendix E), and they completed it alone by forming complete sentences with the given information. A famous soccer player was chosen because soccer culture plays a huge role in Turkey, especially among young people. Speech data was collected and analyzed.

\subsubsection{Error Analysis of Meeting 2}

Tarone and Schwierzbin (2009) define an error as an utterance that is different from how a native speaker may have said it if it were reconstructed, although Cook $(2008 ; 2015)$ notes it isn't really fair to compare L2 learners to native speakers for a variety of reasons. Regardless, recognizing an error is one thing; understanding why an error is made is another. In analyzing L2 learner errors, an attempt is made to explain them and possibly detect their source. This has obvious implications, which are discussed in the conclusion.

In meeting 2, both students made errors with the third person singular $-s$ morpheme in nearly all of their utterances from the elicitation tool. Some of these are presented in Tables 1 and 2 in more detail. 
Table 1. Student T's errors in Meeting 2

\begin{tabular}{|c|c|c|c|c|}
\hline \multicolumn{5}{|c|}{ Student T } \\
\hline$\#$ & $\begin{array}{l}\text { Elicitation Tool } \\
\text { Prompt }\end{array}$ & Error & TL Reconstruction & Possible Cause \\
\hline 1 & $\begin{array}{l}\text { Description: brown } \\
\text { eyes, brown hair, tall }\end{array}$ & $\begin{array}{l}\text { He look likes brown } \\
\text { eyes and brown hair. }\end{array}$ & $\begin{array}{l}\text { He has brown eyes and } \\
\text { brown hair. }\end{array}$ & Intralingual Error \\
\hline 2 & $\begin{array}{l}6.00 \text { - wake up and } \\
\text { eat breakfast }\end{array}$ & $\begin{array}{l}\text { At } 6 \text {, he is wake up and } \\
\text { eat breakfast. }\end{array}$ & $\begin{array}{l}\text { At } 6 \text {, he wakes up and } \\
\text { eats breakfast. }\end{array}$ & Interlingual Error \\
\hline 3 & 11.00 - go to the gym & $\begin{array}{l}\text { After, at } 11 \text {, he goes.. he } \\
\text { go to the gym. }\end{array}$ & $\begin{array}{l}\text { After, at } 11 \text {, he goes to } \\
\text { the gym. }\end{array}$ & Systematic \\
\hline 4 & $10.00-$ get up and eat & $\begin{array}{l}\text { Sunday, he get up and } \\
\text { eat at } 10 .\end{array}$ & $\begin{array}{l}\text { On Sunday, he gets up } \\
\text { and eats at } 10 .\end{array}$ & Systematic \\
\hline 5 & $\begin{array}{l}\text { Hate: snakes, techno } \\
\text { music }\end{array}$ & $\begin{array}{l}\text { She hates... she afraid of } \\
\text { snakes and technology } \\
\text { music. }\end{array}$ & $\begin{array}{l}\text { She hates spiders and } \\
\text { techno music. }\end{array}$ & $\begin{array}{l}\text { Communicating } \\
\text { Strategy }\end{array}$ \\
\hline
\end{tabular}

Table 2. Student B's errors in Meeting 2

\begin{tabular}{|c|c|c|c|c|}
\hline \multicolumn{5}{|c|}{ Student B } \\
\hline$\#$ & $\begin{array}{l}\text { Elicitation Tool } \\
\text { Prompt }\end{array}$ & Error & TL Reconstruction & Possible Cause \\
\hline 1 & $\begin{array}{l}9.00-\text { exercise at } \\
\text { the gym }\end{array}$ & $\begin{array}{l}\text { And then he go to gym } \\
\text { for doing exercise }\end{array}$ & $\begin{array}{l}\text { And then he goes to the } \\
\text { gym to do exercise. }\end{array}$ & Systematic \\
\hline 2 & 19.00 - have dinner & $\begin{array}{l}\text { After all, he feel hungry } \\
\text { and go home, have a } \\
\text { dinner. }\end{array}$ & $\begin{array}{l}\text { After all of this, he feels } \\
\text { hungry and goes home and } \\
\text { has dinner. }\end{array}$ & Systematic \\
\hline 3 & $\begin{array}{l}9.30 \text { - wake up and } \\
\text { eat breakfast with } \\
\text { his wife }\end{array}$ & $\begin{array}{l}\text { On Saturday, he wake } \\
\text { up lately } \\
\text { and..eh..breakfast with } \\
\text { his wife. }\end{array}$ & $\begin{array}{l}\text { On Saturday, he wakes up } \\
\text { late and eats breakfast with } \\
\text { his wife. }\end{array}$ & $\begin{array}{l}\text { Communicating } \\
\text { Strategy }\end{array}$ \\
\hline 4 & $\begin{array}{l}\text { Job: professional } \\
\text { footballer }\end{array}$ & $\begin{array}{l}\text { He work in a football } \\
\text { team and he's } \\
\text { professional footballer. }\end{array}$ & $\begin{array}{l}\text { He works on a football } \\
\text { team and he's a } \\
\text { professional footballer. }\end{array}$ & Systematic \\
\hline 5 & $\begin{array}{l}\text { Like: fashion, } \\
\text { jewelry }\end{array}$ & $\begin{array}{l}\text { She is like fashion and } \\
\text { jewelry. }\end{array}$ & $\begin{array}{l}\text { She likes fashion and } \\
\text { jewelry. }\end{array}$ & Interlingual Error \\
\hline
\end{tabular}

The students' systematic errors show that their underlying knowledge of the target structure has not yet completely developed. Initially, Student T simply read the prompts as they were but was quickly redirected to use complete sentences. Errors like 3 and 4 persisted even after this instruction, and he even self-corrected to the wrong form. Likewise, although Student B produced more novel, creative utterances than Student T (Appendix F), the fact that she made errors even when she changed the words on the elicitation instrument in errors 1, 2, and 4 illustrates that she has also not yet mastered this L2 rule in her IL.

Interlingual errors and intralingual errors were also made. Interlingual errors are those errors that students make as a result of L1 knowledge interference (Larsen-Freeman and Long, 1991). Student T's error 2 and Student B's error 5 were interlingual errors, and they were very similar in nature. There is no copula verb be in Turkish as there is in English, thus it appears they have not yet properly organized how to use verb be versus other verbs in their ILs. As a result, they used both verbs. Student $T$ also made an intralingual error - an error that is made regardless of the student's L1 (Larsen-Freeman and Long, 1991) - as seen in error 1. This may be because he has created an association in his mind between the structure looks like and physical descriptors (associative learning discussed more 
below). However, he still adds the $-s$ onto likes instead of onto looks, which is the actual verb. This may be a result of encountering $\mathrm{He} / \mathrm{Sh}$ likes... so frequently in previous levels that he has associated this particular word with the $-s$ inflection even when it is not being used as a third person singular verb.

Both students also made communication-based errors. These are errors that are a result of communication breakdown, thus calling forth communicative strategies (Larsen-Freeman and Long, 1991). According to Faerch and Kasper (1984), formal avoidance, which involves learners avoiding a particular linguistic form (third person singular $-s$ in this case), is a psychological communication strategy that students employ when they have trouble expressing themselves (Cook, 2008). Student T uses this strategy in error 5 as he restructures his utterance to use a different word. Even though he initially said the correct verb form hates, he is unsure of his construction and resorts to changing the verb completely to [is] afraid of in order to avoid this structure. Student B also uses this avoidance strategy in error 3 as she omits the verb eats completely from her utterance. This strategy is often invoked by learners when they are not comfortable with a particular structure, have not learned how to say it yet, or have moments of doubt, among other reasons (Cook, 2008).

\subsubsection{Interlanguage Analysis of Meeting 2}

Learners' errors and IL development can be better understood if they are dissected from different theoretical viewpoints. As touched on earlier with Student T's intralingual error, associative learning (a construct of Emergentist Approaches) states "the more reliable the mapping between a cue and its outcome, the more readily it is learned," (Ellis and Wulff, 2015, p. 80). Therefore, these learners may be having trouble because the $-s$ cue is not reliably associated with the outcome of third person singular usage. That is, sometimes the $-s$ has a plural or possessive interpretation instead and is thus less salient in meaning. The students' ILs are still tuning themselves to recognize these different patterns, thus errors are likely to occur. Learners' deviations from systematicities of IL development demonstrate that their "language system is constantly engaged in making generalizations and finding abstractions of systematicities," (Ellis and Wulff ibid.: 87). As such, they may just need more time, input, and context in order to further develop their ILs.

However, particularly for the students' systematic errors, Selinker (1972) suggests it may be the case that some L2 learners' errors can't seem to be corrected, no matter what their age is or the amount of explanation or instruction they receive. As a result, the error fossilizes in their IL (Larsen-Freeman and Long, 1991). While Student T and Student B do sometimes make correct utterances using the target structure, it is possible that their correct versions may actually be slips according to the organization of their IL and that the incorrect versions they say more frequently is a fossilized error.

Looking at these students' incorrect productions next to the reconstructed version in Tables 1 and 2 gives an indication of where they are in their language development, regardless of whatever level they may be studying at. Different patterns appear in both of their utterances that are sometimes similar to each other, such as error 2 on Table 1 and error 5 on Table 2, and yet also quite different (Appendix F). When looked at in detail, it is clear just how active learners are in their IL development and that it truly varies from learner to learner.

\subsection{Meeting 3}

The third meeting involved both learners coming together for an interview activity. An elicitation tool (Appendix G) was created so the learners could interact briefly with each other and with the author. Considering goal-oriented tasks can be especially beneficial for L2 learning (Lantolf, Thorne and Poehner, 2015; Donato, 1994; Swain, 2000), each student was required to ask the given questions to the other and take notes on what was said. Student $\mathrm{T}$ asked Task 2(a) to Student B, and Student B asked Task 2(b) to Student T. Then, they had to report what was said to the author as if she hadn't been there. There were also some instances in which the students were prompted further by the author during their interviews as some of their answers were not explanatory or detailed enough. As a result, interaction occurred during the activity beyond the sometimes limited conversational moves common of interviews. Overall, the aim of this meeting was to observe how the students used both the target structure and language to communicate during interaction.

\subsubsection{Analysis of Interaction in IL Development in Meeting 3}

It is believed interaction aids the L2 learning process so much so that current perspectives in SLA argue its L2 facilitative properties cannot and should not be ignored. One such perspective, the Sociocultural Theory, argues that language development takes root during and because of interactions with the environment. Through the use of external mediation tools, including things like dictionaries, other people, and even the language itself, L2 learners gradually move toward self-regulation, that is, having more internal control over their own cognitive and social 
capabilities regarding the L2 (Lantolf, Thorne and Poehner, 2015). Another perspective, the Interaction Approach, believes interaction provides learners with opportunities to get modified input and receive feedback (implicit and explicit) which may draw their attention to problem areas of their interlanguage and push them to produce modified output (Gass and Mackey, 2015). The interaction between Student T, Student B, and the author in the third meeting was analyzed with these two perspectives in mind.

When comparing the interaction of each student, it was clear that Student B was more proficient and used more strategies to communicate than Student T. Student T made more errors both regarding third person singular $-S$ and in general. However, as old classmates, it was obvious that Student B trusted Student T's linguistic abilities as she asked for his help more than once during the interaction, whereas Student $\mathrm{T}$ never asked for any help. This is especially interesting because although Student B appears to be the more proficient one, there are often expert-novice reversals during collaborative interaction. Donato (1994) makes note of the collective expert, which Ohta (2001) highlights as a pooling of learners' strengths and weaknesses that allows them to do together what they cannot do alone (Lantolf, Thorne, and Poehner, 2015). One such example is as follows:

1 Teacher: Of course! What is an example of some advice your mother gave you?

2 Student B: Emm... you can't..yok [no]..you don't love..ehh..who

3 you..who you don't love...(pause) how can I say...(turns to Student T) seni

4 sevmeyeni sevme [don't like someone who doesn't like you]. (laughs)

5 Student T: haaa, she says if you..uhh..don't like you, and you don't like him or her

6 Teacher: hmm, so if you don't like you, you can't like someone else? Like this?

7 Student B: No no

8 Student T: No, um, if you don't like Student B, \{Student B don't like you\}

9 Student B: \{overlapping\} I don't like you

10 Teacher: Ohhh ok! Yes, that's true!

A few other things are also happening in this excerpt. Student B used different strategies to compensate for her inability to express herself. First, she switched back to Turkish when she had trouble, which is something she also did in the first meeting (Appendix C-C./F.). Swain (2000) and her colleagues note that using the L1 can still play a role in regulating cognitive activity in the $\mathrm{L} 2$ as a mediation tool, thus it aids in relieving her stress so she can reorganize her thoughts and get help in trying to express her intended idea in the TL. Student T scaffolds Student B's effort to communicate, and she chimed back in in line 9 when she felt she could adequately perform again. In addition, when she says how can I say in line 3, she engages in private speech, which serves to regulate psychological behavior (Lantolf, Thorne, and Poehner, 2015) by helping her to focus, "organize, rehearse, and gain control over [her] verbal behavior," (Donato, 1994, p. 48). Further still, the students were prompted with a confirmation check in line 6 , which signaled that the teacher had not correctly understood and thus they needed to modify their output and try again. The use of such conversational feedback is a negotiation strategy, which is what conversational participants use when they are trying to compensate for or repair communication breakdowns (Gass and Mackey, 2015).

Both students also used negotiation strategies at other points during meeting 3. Student B once used a confirmation check in Turkish when she was reporting what Student $\mathrm{T}$ said to the teacher by also speaking to Student $\mathrm{T}$ in saying $\mathrm{He}$ [his father] is interested in computer programs, değil mi [right?]? Likewise, when Student B was describing her mother as not so tall, not very short, Student $\mathrm{T}$ used a confirmation check by asking medium?, to which Student B replied yes, medium. Student B's reply here also serves a greater purpose. Her use of yes as an affective marker indicates not only management of the task and information exchange they are working on, but also that the speakers have reached a point of joint focus (Donato, 1994).

Overall, interaction, particularly producing output, pushes learners to process language on a deeper level and may assist them in reaching a more all-encompassing semantic and grammatical cognitive ability that is necessary to both better comprehend and produce the L2 (Swain, 2000). Still, IL variability is an undeniable part of SLA, and it is clear that Student T and Student B have different levels of IL development. Perhaps one reason is because there are differences in the types of mediation tools and L2 strategies they have engaged in. Other reasons may be related to 
their goals, whether and how they negotiate during interaction, and how much attention they pay to specific language forms and meanings (Gass and Mackey, 2015, p. 197).

\section{Conclusion}

Larsen-Freeman and Long (1991) rightly point out that "...with language as complicated as it is, we should not expect the process of language acquisition to be any less complex," (p. 74). There are a seemingly infinite number of variables that affect the outcome of one's language proficiency, and just a few of them have been covered in this paper. We are able to better learn about and comprehend the vastness of SLA through error and interlanguage analyses, especially considering every learner is different and has different L2 learning experiences. It can also lead us to better understand why what is taught is not always learned and vice versa. When viewing IL development and errors from different theoretical lenses, they start to have a deeper meaning, and we realize they are not just the result of 'students not studying enough'. Hamilton (2001) has suggested that errors are just misunderstandings that show learning hasn't occurred yet, but the author is unconvinced. Regarding this case study, witnessing firsthand her students and even herself doing and experiencing many of the constructs and concepts from the numerous approaches and theories of SLA was an incredible experience for her as a language teacher. As such, various professional development and teaching implications arise:

- Tolerance of errors and less student blaming - this kind of clarity can help teachers to better guide students in their IL organization and reorganization

- Identifying where learners are at in their L2 development

- Noticing and appreciating other important aspects of student production outside of errors, like creativity and interaction skills

- Reflecting on task types and teaching to determine if errors may be induced

- Recognizing the difference between an error and a slip/mistake

- The ability to draw comparisons and explicitly address students' errors with them as teachers learn more about the students' L1

- Direction on how to address certain errors, as categorizing errors reveals not all error types call for the same approach

- Developing classroom activities and strategies that allow for more input, practice, feedback, and interaction with certain structures

Errors can be undeniably frustrating for both learners and teachers. However, this kind of analysis and reflection can lead to teachers becoming both more knowledgeable about and better equipped to handle their learners' errors, thus allowing them to meet their leaners' needs more closely. Teachers not only gain a better understanding of how language learning works, but also of how to provide better support for learners in this process as the language teacher.

\section{References}

Cook, V. (2008). Second language learning and language teaching. (4th ed.). London: Hodder Education.

Cook, V. (2015). Working definition of multi-competence 'the overall system of a mind or a community that uses more than one language'. Retrieved 22 March, 2017 from http://www.viviancook.uk/Writings/Papers/MCentry.htm

Cook, V., \& Newson, M. (2007). Chomsky's universal grammar: an introduction (3rd ed.). Malden, MA: Blackwell Publishers.

Corder, S. P. (1967). The Significance of Learner's Errors. International Review of Applied Linguistics in Language Teaching, 5, 1-4. http://dx.doi.org/10.1515/iral.1967.5.1-4.161

Donato, R. (1994). Collective Scaffolding in Second Language Learning. In J.P Lantolf and G. Appel (eds.), Vygotskian Approaches to Second Language Learning. Westport, CT: Greenwood Publishing Group.

Ellis, N.C., \& Wulff, S. (2015). Usage-based Approaches to SLA. In B. VanPatten and J. Williams (eds.), Theories in Second Language Acquisition: an introduction. New York, NY: Routledge. 
Gass, S.M., \& Mackey, A. (2015). Input, Interaction, and Output in Second Language Acquisition. In B. VanPatten and J. Williams (eds.), Theories in Second Language Acquisition: an introduction. New York, NY: Routledge.

Hamilton, R.P. (2001). The Insignificance of Learners' Errors: a philosophical investigation of the interlanguage hypothesis. Language \& Communication, 21, 73-88. https://doi.org/10.1016/S0271-5309(00)00008-2

Kellerman, E. (1985). If at First You Don't Succeed... In S.M Gass and C.G. Madden (eds.), Input in Second Language Acquisition. Rowley, MA: Newbury House Publishers.

Lantolf, J.P., Thorne S.L., \& Poehner, M.E. (2015). Sociocultural Theory and Second Language Development. In B. VanPatten and J. Williams (eds.), Theories in Second Language Acquisition: an introduction. New York, NY: Routledge.

Larsen-Freeman, D., \& Long, M. (1991). An Introduction to Second Language Acquisition Research. New York: Longman.

Swain, M. (2000). The Output Hypothesis and beyond: Mediating Acquisition through Collaborative Dialogue. In J. P. Lantolf (ed.), Sociocultural Theory and Second Language Learning. Oxford: Oxford University Press.

Tarone, E., \& Swierzbin, B. (2009). Exploring Learner Language. New York: Oxford University Press.

VanPatten, B., \& Williams, J. (2015). Early Theories in SLA. In B. VanPatten and J. Williams (eds.), Theories in Second Language Acquisition: an introduction. New York, NY: Routledge.

Appendix A

Planned Interview Questions for Meeting 1

1. Why are you learning English?

2. How will you use English in the future?

3. How do you study?

4. How do you feel about 'language learning'?

5. How do you feel about English?

6. Do you know anyone who knows another language?

- How did they learn it?

-What do you think about them?

7. Do you know any other languages?

- How did you learn it?

8. Have you studied any other languages?

- When?

- Where?

- How?

- What was it like?

- How long?

9. Did you study English before coming to Ekonomi (Izmir University of Economics)?

-Where?

- How long?

- What was it like?

- How did they study?

10. Have you ever travelled abroad?

- Did you use English?

11. Where do you live?

- Does this affect your English learning?

12. Who helps you learn and study?

13. Do you want to learn another language (besides English)? 


\section{Appendix B \\ Student T - Meeting 1 Transcriptions}

A.

Teacher: Why are you learning English?

Student T: Why? Because world's developing quickly and everywhe..eh..every people speaks English. I must speak English because..I..uh..(pause) chased new things or new areas

\section{B.}

T: How do you feel about language learning? Not English, not Spanish, but language generally?

ST: very good yani (you know), it's..I believe that very good because you..eh..learn new things, new cultures, and new information for country..eh..i think cool

\section{C.}

T: How do you feel about English? Specific language, English.

ST: uh..mm..(pause) how do you feel?

T: Some students are angry because they must learn English. How do you feel about English?

ST: Hah, eh, I don't have a action because English same as subject yani (you know)

\section{D.}

T: Do you know anyone who knows another language?

ST: eh..my classmates speaks Turkish..eh..but m-my friends speaks Russian, and..eh..other friends speaks Azerbijani..same as Turkish

T: And do you know how they learned it?

ST: uh..my friend go to university in Russia and she develop..eh..yourself..uh..but other friends..eh..live in Azerbaijan, and he know it

\section{E.}

T: um, in the past, have you studied any other languages?

ST: Yes, Spanish..eh..i start at high school..eh..you selected..select two other languages..eh..Germany..eh..(pause) German..and Spanish..I selected Spanish but I don't know..one or two words I know

T: Cool. Did you like studying Spanish?

ST: Yes, but..eh..Turkish education system..eh..not..eh..useful for learning new languages because..eh..in the last class you must enter the university exam, and..eh.. only focusing..focusing Turkish maths, chemistry, etcetera.

F.

T: I see. And did you study English before you came to Ekonomi?

ST: Yes..eh..in Turkey..eh.. (pause) we are must study English in high school or primary school, but..eh..not good T: And how long did you study English before Ekonomi?

ST: eh.. 8 years

T: And again, what was it like? Again only grammar? Or...

ST: uh..i think speaking is very..m-more important than grammar because..eh..if you are study..if you are speaking English or other languages..eh..maybe you studying grammar

G.

T: Ok. So, where do you live in Izmir?

ST: near the school, Balcova

T: And does this help you learn English?

ST: No because..eh..everyone speaks Turkish..eh...not good..studying in English..Balçova 
H.

T: Who helps you learn and study?

ST: Teachers. Sometimes my sister. She know very well English because she lived in America 4 years. Eh..my father.. (pause)..work in America

I.

T: Do you want to study another language?

ST: Yes. Italian because..eh.. architecture..ehh..my faculty is architecture..and generally architects uses Italian or English

\author{
Appendix C \\ Student B - Meeting 1 Transcriptions
}

A.

Teacher: Why are you learning English?

Student B: Because it's necessary for my future, for my life. Because everybody..eh..talk English now

$\mathrm{T}$ : True. Ok, and how will you use English in the future?

SB: eh..I will use..to my job..eh..communications and emails..it's need English

B.

T: And how about your department?

SB: Industrial Engineering my department. And..eh..Industrial Engineering really needs English because this job..eh..popular in the America. And American's language is English

C.

T: And generally, how do you study?

SB: How am I study? Ehh..I study..eh...write words and I..em..okurum işte yani [I read, ya know]

\title{
D.
}

T: How do you feel about English in general? Not learning English, but English language. How do you feel about English?

SB: I think it's unnecessary..eh..words..it's have. Because..eh..(pause) every..everything it's long. We not use them in Turkish. We always..em..say shorts sentence.

\section{E.}

T: Do you know anyone who knows another language?

SB: Yes, my uncle

T: Really? Which languages?

SB: A lot of language. And my father's aunts, he learn 8 language, and only listening she learned

T: Really? So she learned only by listening?

SB: Yes, only listening. Eh..D\&R..eh..sell..eh..these CDs, DvDs, and she heard and learned. And she travel around the world. And she is 80 years old

F.

T: Did you study English before coming to Ekonomi?

SB: Yes, I study English since I was 10, I think.

T: So, in high school, or with your family? How did you study?

SB: Yes, school. I go..uh..third..fourth..eh...cla..fourth..(laughs)..dördüncü sinıftaydım yani [I was in fourth class [grade]]

T: Fourth grade?

SB: Yes, fourth grade. 
Appendix D

Examples of Turkish Word Order

\section{Standard spoken utterance example:}

*italics used to show emphasis in English intonation

1. Ben (I - subject - can be omitted) cevab1 (the answer - object) biliyorum (know - first person marker $(-\mathrm{um}=\mathrm{I})$ - verb)

Translation: (I) the answer I know.

English Equivalent: I know the answer.

2. Balçova (neighborhood name - subject) İngilizce (English - object) çaliskmak için iyi değil ((is) not good to study - verb)

Translation: Balçova to study English (is) not (a) good (place).

English Equivalent: Balçova is not a good place to study English.

Example of change in word order to highlight the action or object in spoken utterance and English equivalent:

1. Biliyorum (know - first person marker $(-\mathrm{um}=\mathrm{I})$ - verb) ben ( $\mathrm{I}$ - subject - can be omitted) cevab1 (the answer - object)

Translation: I know (I) the answer.

English Equivalent: I *know the answer.

2. İngilizce (English - object) çaliskmak için iyi değil ((is) not good to study - verb) Balçova (neighborhood name - subject)

Translation: English to study (is) not (a) good (place) Balçova.

English equivalent: Studying English in Balçova is not good.

Appendix E

Elicitation Instrument for Meeting 2

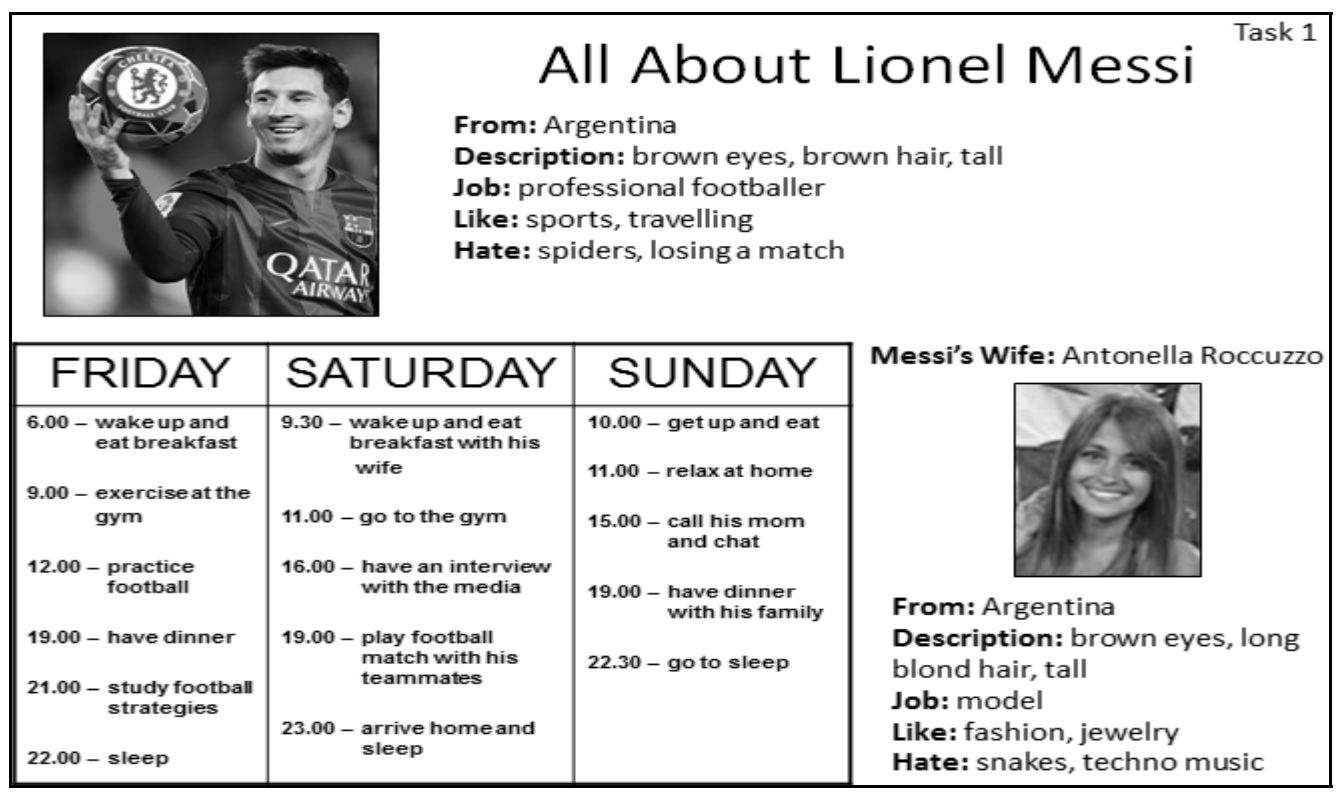


Appendix F

Sample Utterances Comparing Creativity between Student T and Student B in Meeting 2

\begin{tabular}{|c|l|l|l|}
\hline Student T & $\begin{array}{l}\text { Elicitation Tool } \\
\text { Prompt }\end{array}$ & $\begin{array}{c}\text { Original } \\
\text { Utterance } \\
\text { dinner }\end{array}$ & $\begin{array}{c}\text { Th } \\
\text { Reconstruction }\end{array}$ \\
\hline Student B & $\begin{array}{l}\text { At 7, have a } \\
\text { dinner. }\end{array}$ & $\begin{array}{l}\text { At 7, he has } \\
\text { dinner. }\end{array}$ \\
dinner & $\begin{array}{l}\text { After all, he feel } \\
\text { hungry and go } \\
\text { home, have } \\
\text { dinner. }\end{array}$ & $\begin{array}{l}\text { After all of this, } \\
\text { he feels hungry } \\
\text { and he goes } \\
\text { home and has } \\
\text { dinner }\end{array}$
\end{tabular}

Sample 1

\begin{tabular}{|c|c|c|c|}
\hline & $\begin{array}{c}\text { Elicitation Tool } \\
\text { Prompt }\end{array}$ & $\begin{array}{l}\text { Original } \\
\text { Utterance }\end{array}$ & $\begin{array}{c}\text { TL } \\
\text { Reconstruction }\end{array}$ \\
\hline Student T & $\begin{array}{l}\text { Job: Model } \\
\text { Like: fashion, } \\
\text { jewelry }\end{array}$ & $\begin{array}{l}\text { She is } \\
\text { model..and..eh.. } \\
\text { she..em...she } \\
\text { like fashion } \\
\text { and jewelry. }\end{array}$ & $\begin{array}{l}\text { She is a model } \\
\text { and she likes } \\
\text { fashion and } \\
\text { jewelry. }\end{array}$ \\
\hline Student B & $\begin{array}{l}\text { Job: Model } \\
\text { Like: fashion, } \\
\text { jewelry }\end{array}$ & $\begin{array}{l}\text { She is model, } \\
\text { and..eh..she is } \\
\text { like fashion } \\
\text { and jewelry, } \\
\text { maybe..eh..this } \\
\text { is reason she a } \\
\text { model. }\end{array}$ & $\begin{array}{l}\text { She is a model } \\
\text { and she likes } \\
\text { fashion and } \\
\text { jewelry. Maybe } \\
\text { this is the/one } \\
\text { reason she is a } \\
\text { model. }\end{array}$ \\
\hline
\end{tabular}

Sample 2 
Appendix G

Elicitation Instrument for Meeting 3

\section{Interview}

Task 2 (a)

- What is your mother like?

- Why is she important to you?

- Who is your best friend?

- Why is he/she your best friend?

Student T’s Questions to Ask Student B

\section{Interview}

Task 2 (b)

- What is your father like?

- Why is he important to you?

- Who is your role model?

- Why is he/she your role model?

Student B's Questions to Ask Student T 